\title{
Okul öncesi eğitim kurumlarında çölyak hastalığ1 yönetimi: Öğretmenin rolü ve sorumlulukları
}

\section{Celiac Disease Management in Preschool Education Institutions: The Role and Responsibilities of the Teacher}

\author{
Gürcühan Fidan ${ }^{1}$, Deniz Çalışkan²
}

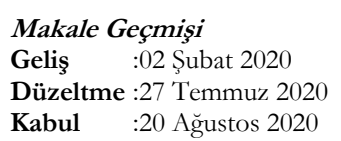

Makale Türü

Derleme Makale

\section{Article History}

Received :02 February 2020

Revised :27 July 2020

Accepted :20 August 2020

Article Type

Review Article

\begin{abstract}
Öz: Tahıl ürünleri Türkiye dahil olmak üzere birçok ülkenin önemli besin kaynağını oluşturmaktadır. Ancak tahıl ürünlerinde bulunan ve bir protein olan glüten, genetik olarak yatkınlı̆ı olan bireylerde kronik ince bağırsak hasarlarına neden olmaktadır. Çölyak hastalı̆̆ı olarak bilinen bu hastalık glütene maruziyet ile birlikte belirti gösteren, glütensiz diyeti gerektiren, ömür boyu süren otoimmün bir hastalıktır. Çölyaklı bireylerin sayısı, tanı olanaklarının artması nedeniyle gün geçtikçe artmaktadır. Ek gıdanın diyete eklendiği yaşamın ilk üç yıllında daha sık olmak üzere tüm yaş gruplarında görülmektedir. Bu nedenle Çölyak hastalığının tanısı ve tedavisinde çocuklar, aileleri ve okul öncesi eğitim kurumlarına önemli görevler düşmektedir. Okul öncesi, pek çok alışkanlığın kazanıldığı bir dönemdir, doğru yöntemlerle verilen beslenme eğitimleri ile çocuklar daha sağlıklı büyür, daha sağlıklı yetişkinler haline gelirler. Okul öncesi dönem, sağlık sorunları nedeniyle özel beslenme gereksinimi olan çocukların sağlıklarının geliş̧irilmesi, hastalıklarının ilerleyişi açısından da önemlidir. Çalışmada, okul öncesi kurumlarında çölyak hastalığının yönetiminde öğretmene düşen rollerin ve öğrencinin sınıf içinde damgalanmasının engellemesinin öneminin ortaya konması amaçlanmaktadır.
\end{abstract}

Anahtar Kelimeler: Çölyak, Okul Öncesi, Öğretmen, Beslenme, Glütensiz Diyet, Damgalama,

\begin{abstract}
Grain products are an important food source in many countries, including Turkey. However, gluten, a protein found in cereal products, causes chronic small intestine damage in genetically susceptible individuals. This disease, known as celiac disease, is a lifelong autoimmune disease that indicates gluten exposure and requires a gluten-free diet. The number of people with celiac disease is increasing day by day due to the increase in diagnostic means. It is seen in all age groups, often in the first three years of life, when supplementary food is added to the diet. Therefore, preschool education institutions have important duties in the diagnosis and management of the disease. Preschool is a period in which habits are acquired and healthy individuals are provided with effective nutritional education. This study aimed to highlight the importance of teachers' role in celiac disease management prevent stigmatization of students at school.
\end{abstract}

Keywords: Celiac, Preschool, Teacher, Nutrition, Gluten Free Diet, Stigmatization

DOI: $10.24130 /$ eccd-jecs.1967202043227

*Bu çalışma Ankara Üniversitesi Halk Sağlığ̣ Hemşireliği Anabilim Dalı ‘Ankara İl Merkezinde Okul Öncesi Öğretmenlerin Çölyak Bilgi Düzeyi ve İlișkili Etmenler` adlı Yüksek Lisans tezinden üretilmiștir.

Gürcühan Fidan ${ }^{1}$ Ankara Üniversitesi Sağlık Bilimleri Enstitüsü Halk Sağlı̆̆ Hemşireliği Yüksek Lisans Programı Öğrencisi. grchn_fdn92@hotmail.com ORCID: https://orcid.org/0000-0002-0943-5612

Deniz Çalışkan² Ankara Üniversitesi Tıp Fakültesi Halk Sağlığı Anabilim Dalı, Öğretim Üyesi. Deniz.Caliskan@medicine.ankara.edu.tr. ORCID: https://orcid.org/ 


\section{SUMMARY}

\section{Introduction}

The development levels of the socio-economic structures and dietary habits keep changing constantly. However, cereals remain the major source of food for people all around the world and in Turkey. Cereals are very for people, but they also can cause a number of diseases. Celiac disease is one of them (Türksoy and Özkaya, 2006).

Celiac disease is an autoimmune disease that occurs due to consumption of grain (barley, oats, rye) in genetically susceptible individuals. Gluten, a protein found in cereals, causes the disease (Kuloğlu, 2013). The number of patients is increasing parallel to advancing diagnostic methods and raising awareness (Ministry of National Education, Turkey, 2018).

This study aims to emphasize the importance of gluten-free diets in preschool children with Celiac disease, prevent stigmatization of affected students at school to raise awareness of preschool teachers on this subject.

\section{Celiac Disease}

Celiac disease (gluten sensitive enteropathy) is a lifelong autoimmune disease that progresses with gastrointestinal and extraintestinal (non-gastrointestinal) symptoms and signs due to gluten consumption in individuals with genetic predisposition (Mokhtari, 2012). Celiac disease can occur at any time in life. However, the most common age group is between the ages of 1-3, when gluten is introduced to the diet (Aş1k, 2019; Elliiki, 2019). In Turkey, the incidence of Celiac disease from $0.3 \%$ to $1 \%$. The estimated number of cases varies between 250000 and 750000 . Given that diagnosis rate is approximately $10 \%$, the number of cases is roughly 25000 - 75000 (Grand National Assembly of Turkey, 2018).

\subsection{Clinical Signs and Findings}

Gastrointestinal symptoms: Diarrhea, weight loss and abdominal swelling concurrent with malabsorption are the typical signs of the disease (Yönal and Özdil, 2014).

Extraintestinal symptoms: One of the most common extraintestinal findings is iron deficiency anemia, vitamin D deficiency, and metabolic bone disease due to calcium deficiency (Yönal and Özdil, 2014).

\subsection{Diagnosis and Treatment}

Diagnosis in Celiac disease is made by serological tests and small intestine biopsy. Biopsy findings are the gold standard in diagnosis (Serin and Akbulut, 2017).

The only treatment for the disease is compliance with a strict and lifelong gluten-free diet (Tanpowpong et al, 2011). Healthy growth and development can be achieved through nutrition compliance and other problems that may occur later can be prevented. However, in cases where the diet is not started or adapted, diseases such as growth and development retardation, anemia, vitamin deficiency, dental caries, thyroid 
disease, osteoporosis, cancer and diabetes may develop in children (Ministry of National Education, Turkey, 2018).

\section{Celiac in Preschools}

Societies need physically and mentally healthy individuals to develop. To achieve this, the population needs to have adequate and balanced nutrition. Healthy eating habits should be considered a lifestyle from early ages. The way to gain this habitat young ages is through education (Sedakatll, 2019). Methods to improve patients' knowledge of the disease and patient-specific education can help patients overcome disease-related problems by altering their behavior and attitudes (Barzegar et al., 2017). Especially the determination of the student with Celiac disease in the preschool period, the level of knowledge and awareness of the preschool teacher about the importance of the subject is very important for the cognitive, mental and psychological development of the student.

Therefore, more attention should be paid to this subject in preschool institutions as many skills including eating habits are developed in this period of life which is very important for an individual's whole learning process.

\subsection{Teachers' Roles in Celiac Disease Management}

In order to maintain health and a healthy society, it is necessary to create a healthy lifestyle model that can be taught to students in preschool institutions. Since children spend most of their time in educational institutions, this model should be developed and implemented by school administrations and teachers (Şahinöz, Şahinöz and Kıvanç, 2017).

Increasing the level of knowledge and awareness of educators, who play a role in the development of the child's physical, physical and psychological health in this period, is also important (Clark, 2015).

\subsection{Access to Food}

Kindergartens and other institutions preschool education is provided are educational settings where children spend most of the day, and the meals provided at school must meet nutritional requirements of the children (Çetin, 2019).

\subsection{Social Events}

The signs and symptoms of celiac disease reappear after exposure to gluten, even in trace amounts (Clark, 2015). Gluten is present not only in the foods we eat, but also in the materials used, even in trace amounts. Prevention of this transmission within the school depends on the level of knowledge of the teacher on the subject. In particular, exposure to these substances affects children's thought processes, emotions, behavior and social interactions (Clark, 2015). 


\subsection{Psychological State}

Managing Celiac disease and gluten-free nutrition can be difficult because they often feel isolated and differ from those around them (Darling, 2013). Changes can be made in the physical environment to encourage the student to be involved in activities, but it is not always possible to access gluten-free products, which requires cooperation with the family (Clark, 2015).

The lack of knowledge of teachers about Celiac disease and stigma often triggers the beginning of a very difficult process for the student. Stigmatization of the student in the school and most importantly in the classroom should be avoided.

\section{Conclusion and Recommendations}

Celiac disease is not only a nutritional problem, but it also affects the patient's social and psychological quality of life until a full compliance with the diagnosis and treatment process is achieved.

During the first encounter with students, obtaining information about their health status is very important in identifying those who may have health problems. This information should guide educational activities to be organized in the school. 


\section{GİRİŞ}

Ülkelerin gelişmişlik düzeyi, sosyo-ekonomik yapıları ve bireylerinin beslenme alışkanlıkları günden güne değişmekle birlikte tüm dünyada ve Türkiye'de tahıl ürünleri, toplumların en önemli besin kaynağı haline gelmektedir. Tahıllar insanlar için bu derece önemli olmalarına rağmen bazı hastalıklara neden olabilmektedirler. Bu hastalıklardan birisi de çölyak hastalığıdır (Türksoy ve Özkaya, 2006).

Çölyak hastalığı, genetik olarak yatkın olan bireylerde tahıl (arpa, yulaf, çavdar) tüketimine bağlı olarak ortaya çıkan otoimmün bir hastalıktır. Hastalığın görülmesine neden olan şey tahıllarda bulunan bir protein olan glütendir (Kuloğlu, 2013). Hastalığın teşhis ve tanı yöntemlerinde olan gelişme ve hastalığa olan farkındalığın artması sonucunda tanı alan hasta sayısı artmaktadır (Türkiye Cumhuriyeti Milli Eğitim Bakanlığı[MEB], 2018).

Bu çalışmada; çölyak hastalığı olan okul öncesi çocuklarda glütensiz diyetin önemini vurgulamak ve öğrencinin okul/sınıf içerisinde hastalı̆̆ından dolayı damgalanmasını engellemek, okul öncesi öğretmenlerinin ve okul yöneticilerinin bu konularda farkındalı̆̆ını arttırmak amaçlanmaktadır.

\section{1. Çölyak Hastalığı}

Çölyak hastalığı (glütene duyarlı enteropati), genetik yatkınlığı olan bireylerde glüten tüketimine bağlı olarak gastrointestinal ve ekstraintestinal (gastrointestinal dışı) belirti ve bulgular ile seyreden, yaşam boyu devam eden otoimmün bir hastalıktır (Mokhtari, 2012). Çölyak hastalı̆̆ yaşamın herhangi bir döneminde ortaya çıkabilmektedir. Ancak en sık ortaya çıktığı yaş grubu glütenin diyete eklendiği yaş olan 1-3 yaşları arasıdır (Aşık, 2019; Elliiki, 2019). Türkiye'de çölyak hastalığ1 görülme sıklığ1 \%1-\%0.3 arasında değişmektedir ve 250 bin ile 750 bin arasında çölyak hastası olduğu tahmin edilmekte iken ancak yüzde 10'una tanı konulduğu dikkate alındığında 25 bin ile 75 bin arasında tanı almış hasta beklenmektedir (Türkiye Büyük Millet Meclisi [TBMM], 2018). Yine Türkiye'de çocuklarda çölyak hastalığı sıklı̆̆ını belirlemek için 2006-2008 yıllarında 20.190 sağlıklı okul çocuğunda yapılan bir çalışmada çölyak hastalığı görülme sıklığı \% 0.47 olarak bulunmuştur (Emiroğlu ve diğerleri., 2017). Araştırmalar sonucunda ortaya çıkan bu veriler çölyak hastalığının tanısal sıklı̆̆ının arttığını gösterse de hala tanı almayan kısmı büyük orandadır ve çölyak hastalığı tanısı alan her bir hastaya karşın 1:3-1:5 oranında tanı almayan çölyak hastası bildirilmiştir (TBMM, 2018). Giderek artan bir sıklığa sahip olan çölyak hastalığı tedavi edilmediği taktirde çok ağır sonuçlar doğurduğundan tespiti oldukça önemlidir. 


\subsection{Klinik Belirti ve Bulgular}

Hastalığın klinik özellikleri, hastanın yaşına, hastalığın süresine-yaygınlığına ve ekstraintestinal bulguların olup olmamasına göre değişkenlik göstermektedir (Küçükazman, Ata, Dal ve Nazligül, 2008).

Gastrointestinal semptomlar; Malabsorbisyon (bağırsakta, besin, vitamin ve eser elementlerinin emilim bozukluğu) ile görülen ishal, kilo kaybı ve karında belirgin şişlik hastalığın klasik belirtisidir (Yönal ve Özdil, 2014). Gaz, karın ağnısı, kusma, ishal ve dışkı şekilsiz cıvık ve kötü kokuludur (Aş1k, 2019).

Ekstraintestinal semptomlar; en sık rastlanan ekstraintestinal bulgulardan birisi demir eksikliği anemisi ve vitamin D eksikliği, kalsiyum eksikliğine bağlı olarak gelişen metabolik kemik hastalığıdır (Yönal ve Özdil., 2014).

\subsection{Tanı ve Tedavi}

\subsubsection{Tan1}

Çölyak hastalığında tanı, serolojik (kan) testler ve ince barsak biyopsisi ile konur. Biyopsi bulguları tanida altın standarttır (Serin ve Akbulut, 2017).

Erken tanı her hastalıkta olduğu gibi çölyak hastalığında da hayati önem arz etmektedir. Çölyak hastalığı erken dönemde karın ağrısı, şişlik, devam eden ishal, dehidratasyon (sıv1 kaybı) bulguları ile kendisini gösterirken ileri ki dönemlerde elektrolit dengesinde değişiklikler ile karakterize çölyak krizi olarak adlandırılan ve yoğun bakım şartlarında acil müdahaleyi gerektirecek tabloya kadar değişebilen bulguları içerir (Çakmak, 2013). Ancak buna karşılık çölyak hastalığının hiç belirti vermeden asemptomatik (belirtisiz) diye tabir edilen türleri de vardır. Bu bağlamda bakıldığında erken tanı ve tarama ile gerçekleşebilecek her türlü olumsuz durumların önüne geçilebilmektedir. Çölyak hastalığının klinik septomlarından (belirti) olan,

- Kronik ishal, karında şişlik, kilo kaybı, malabsorbisyon gibi semptomları bulunduran kişiler,

- Çölyak hastalığı olan kişinin birinci ve ikinci derece yakınları,

○ Tip1 diyabet ve otoimmun endokrin hastalığ1 olanlar, 
- Erken osteoporozu (kemik erimesi),

- Açılanamayan transaminaz yüksekliği,

○ Demir eksiliği anemisi,

○ İzole alkalen fosfataz yüksekliği,

○ Boy kısalığ1,

○ Gecikmiş puberte (Ergenliğin gecikmesi),

○ İnfertilite (Kısırlık)

- Tekrarlayan düşükleri olan, Turner ve Down sendromu olanlar çölyak hastalığı açısından taranmalıdır (Yönal ve Özdil, 2014).

\subsubsection{Tedavi}

Hastalığın tek tedavisi katı ve yaşam boyu glütensiz diyete uyumdur (Tanpowpong ve diğerleri, 2011). Glütensiz diyete bağlllık her yaşta oldukça zordur. Bu nedenle hastanın ve ailenin çölyak hastalı̆̆ ve tedavisi için glütensiz diyetin gerekliliği hakkında geniş bilgiye sahip olmaları gerekmektedir. Tanı koyulduktan sonra hastanın diyetindeki değişiklik sadece hastayı değil ev içerisindeki diğer aile bireylerini hatta çevresindeki diğer kişileri de etkilemektedir (öğretmen, arkadaşlar vb.). Meyer ve Rosenblum (2017) göre; 'çölyak hastalığını iyi yönetmek ve glütensiz diyete uyumlarına yardımcı olabilmek için çölyaklıların günlük aktivite ve rutinleri dikkatlice incelenmelidir'.

Çölyak hastalığı tanısı koyulduktan sonra diyete geçilmesi ve diyete tam uyum sonrası ilk iki hafta içinde hastalık yakınmalarında \%70 oranında azalma görülmektedir (Özkaya ve Özkaya, 2018; Bulsa ve Bulsa., 2018). Beslenmeye uyum ile sağlıklı büyüme ve gelişme sağlanabilmekte ve daha sonra oluşabilecek diğer sorunların da önüne geçilebilmektedir ancak diyete başlanmadığı ya da uyum sağlanmadığı durumlarda, çocuklarda büyüme ve gelişme geriliği, anemi, vitamin yetersizliği, diş çürükleri, trioit hastalıkları, kemik erimesi, kanser ve diyabet gibi hastalıklar görülebilmektedir (MEB, 2018).

\section{Okul Öncesi Kurumlarda Çölyak}

Toplumların gelişmişlik seviyelerine ulaşabilmeleri için bedenen ve ruhen sağlıklı bireylere ihtiyacı vardır. Bunu sağlamak için toplum üyelerinin yeterli ve dengeli beslenmesi gerekmektedir. Doğru beslenme alışkanlığ ise küçük yaşlardan itibaren bir yaşam tarzı haline getirilmelidir. Bu alışkanlığı küçük yaşlarda kazandırmanın yolu ise eğitimden geçmektedir (Sedakatlı, 2019). Ancak, eğitim sadece çölyak hastalığı olanlar için değil, aynı zamanda aile üyeleri, arkadaşlar, öğretmenler ve 
diğer destekçiler için de önemlidir (Darling, 2013). Hastaların, hastalıkla ilgili bilgilerini geliştirmeye yönelik yöntemler, hastaya özgü eğitim hastanın, davranış ve tutumlanında değişikliklere yol açarak hastalıklarla ilgili sorunların üstesinden gelebilmesine yardımcı olabilir (Barzegar ve diğerleri, 2017). Özellikle okul öncesi dönemde çölyak hastalığı olan öğrencinin tespiti, okul öncesi öğretmeninin konunun önemi ile ilgili bilgi düzeyi ve farkındalığı gibi etkenler öğrencinin bilişsel, zihinsel ve psikolojik gelişimi üzerinde büyük bir öneme sahiptir.

Glütensiz diyet, hastalığa ait belirti, bulgu ve komplikasyonları azaltsa da diyete uyum oldukça zordur (Yıldız ve Civan, 2019). Beslenme alışkanlığının yeni kazanılmaya başlandığı, öğrenim sürecinin en önemli basamaklarından biri olan okul öncesi dönemde edinilen beceriler yaşamın bütün evrelerini etkilediğinden, okul öncesi kurumlarında bu konuya daha fazla önem verilmesi gerekmektedir. Okul öncesi dönemden itibaren çocuğa verilen tüm beceriler gibi beslenme becerisini kazanma ve bu konuda yapılacak uygulamalar çocukların beslenme ile ilgili bilgi düzeylerini olumlu yönde etkilemekte ve diyetin önemi bu dönemde kazandırıldığında ilerleyen yaşlarda diyete uyum, çocuk için daha kolay olmaktadır (Zembat, Kılıç, Ünlüer, Çobanoğlu, Usbaş ve Bardak, 2015; Gündüz, Çizmeci ve Kanburoğlu, 2013).

Sağlığı korumak geliştirmek ve sağlıklı bir toplum için anaokullarından itibaren öğrencilere yaşam boyu uygulayabilecekleri sağlıklı yaşam modeli oluşturmak gerekmektedir. Çocuklar, zamanlanının büyük bir kısmını eğitim kurumlarında geçirdiklerinden bu model okullarda okul yöneticileri ve öğretmenler tarafindan geliştirilmeli ve uygulanmalıdır (Şahinöz, Şahinöz ve Kıvanç 2017). Sağlıklı yaşam modelinin oluşturulmasında, okul ortamında çocukların öğretmenlerinin davranışlarından etkilenmesi avantaja çevrilerek sağlanabilir (Akder, Meseri ve Çakıroğlu, 2018). Ancak yapılan bazı çalışmalar göstermiştir ki okul öncesi öğretmenleri eğitimleri boyunca sağlık eğitimini ya yetersiz ya da hiç almamışlardır (Gündüz ve ark; 2013).

Okul, çocukların hayatında önemli bazı değişiklikleri beraberinde getiren bir dönemdir. Bu dönemde ailenin yerini önemli oranda akranlar ve öğretmenler almaktadır. Ancak kronik bir hastalığa sahip öğrencinin hayatında bu durum bazı temel sorunlara sebep olmaktadır. Sosyal ilişkilerden uzak durarak hastalığa bağlı yetersizliklerini saklamaya ya da farklılıklarla mücadele etmeye çalışabilir, kendilerini akranlarından uzaklaştırarak yalnızlık, izolasyon ve aidiyet duygularının azalmasına neden olabilir. Bu durumun düzeltilmesi, akranları ile kurduğu sağlıklı ve anlayışlı sosyal ilişkiler ile düzenlenebilir. (Yılmaz, 2008). Okul içerisindeki sosyal ilişkilerin de düzenleyicisi olan okul öncesi öğretmeninin hastalık hakkında bilgisinin ne düzeyde olduğu çok önemlidir. Yapılan bazı çalışmalarda, öğretmenlerin hastalıklar hakkındaki yetersiz bilgiye sahip 
oluşları çocuğa karşı davranışlarını düzenleme ve hastalığın etkilerini gözlemleme ve fark etmede kendilerini güvensiz hissettiklerini göstermektedir (Y1lmaz, 2008). Sınıf içerisinde çocuğun dikkatinin dağınık olması, halsizliği, sosyal etkinliklere katılmayışı ve çekimserliği hastalıktan kaynaklanabilir ancak bu konu hakkında yeterli bilgiye sahip olmayan öğretmenler bunu derse/okula ilgisizlik, tembellik olarak adlandırabilirler.

Çölyak hastalığı gibi özel diyet gereksinimini zorunlu kılan hastalıklara sahip çocuklar, sosyal ortamlarda akran baskısına altında kalabilmekte ve diyetlerini çiğneyebilmektedirler. Diyet gerektiren bu tarz hastalıklarda temel amaç çocukların, sosyal, psikolojik gelişimini en üst seviyede tutmak olmalıdır (Altundağ, 2018). Bu durumda, akranlar arasındaki etkili iletişimi sağlayacak olan ve çocuğun bu dönemde fiziksel, bedensel ve psikolojik sağlığının gelişiminde katkı sağlayacak olan okul öncesi öğretmenleridir.

Öğrencinin okulda beslenmesi ile ilgili edinmiş olduğu farkındalık çok önemlidir. Çocuğun bu dönemde almış olduğu beslenme alışkanlığı hayatının diğer dönemlerini de şekillendirmektedir. Sağlıklı beslenme davranışı ile kardiyovasküler hastalıklar, diyabet, kanser, obezite, çölyak hastalığı gibi kronik sağlık problemlerinin yanı sıra beslenme, malnütrisyon, büyüme geriliği gibi akut sağlık sorunlarının da önüne geçilebilmektedir (Aktaç, Kızıltan ve Avcı, 2019).

Tüm bunların yanı sıra doğru beslenme kişinin yapısına, cinsiyetine, tanılı hastalığı varsa hastalığına ve özel durumlara göre değişmektedir. Özel beslenme örüntüsünü içeren çölyak hastalığı da yaşam boyu glütensiz diyeti gerektiren otoimmün bir hastalıktır ve eser miktarda bile olsa glütene maruziyetten birkaç dakika sonrasında belirtiler gözlenebilmektedir (Clark, 2015).

Çölyak ve diğer hastalıkların öğretmen tarafından tespiti ve yönetimi için öğrenci ile ilk karşılaşmada ve hizmet içi çalışmalarda öğretmenler; (Celiace Canadian Association [CCA], 2007).

○ Sınıfa yeni öğrenci katıldığında çölyak ve diğer sağlık sorunları konusunda bilgi edinmeli,

○ Sınıfta çölyak vb. sağlık sorunu olan öğrenci var ise sınıf yönetimi ve eğitim programında var olan sağlık sorununa yer verilmeli, ayrımcılık ve damgalamamaya özen gösterilmeli,

○ Okul yönetimi ile konu paylaşılmalı,

- Aile ve aile hekimi ile iş birliği içerinde olunmalı,

○ Okulda kantin, yemekhane vb. olanakların işletmeleri ile glütensiz gıda bulundurulması konusunda iletişim kurulmalı, 
○ Çölyaklı ya da diğer hastalıkların öğrenci/çalışanlarda varlığ1 fark etmeksizin öğretmenlerin eğitim programında ilgili hastalığın /çölyak tanımı, çeşitleri, belirtileri, tanı ve tedavisi konularına yer verilmeli,

○ 'Çölyak bulaşıcı bir hastalık değildir' bilgisini diğer öğrencilere ve okuldaki öğretmen ve yöneticilere fark ettirmeli,

○ Okul ortamında öğrencinin psiko-sosyal durumu açısından ayrımcılık, damgalama gibi durumları içermeden farklılıkların kabullenmesine olanak sağlanmalı,

○ Tüm okul çalışanları çölyaklı yaşam konusunda bilgilendirilmeli,

○ Okulda çölyaklı öğrencinin varlığı durumunda okul ortamında bilgilendirmelerin daha detaylı olmasına dikkat edilmeli,

○ Okulda yürütülen çalışmalar raporlanmalı ve bir sonraki yıl yapılacak faaliyetler belirlenmesi konularına yer vermelidir.

Türkiye Cumhuriyeti Milli Eğitim Bakanlığı'nın Okul Sağllğı Hizmetleri kapsamında 'Çölyakla Mücadele Konusunda Yapılacak Çalışmalar' adlı çalışmasında (MEB, 2018);

1. 9 Mayıs Dünya Çölyak Günü’ nün bulunduğu hafta içerisinde resmi ve özel okul/kurumlarda, okul/kurum yönetimleri tarafından; öğrenci, öğretmen, veli, yemekhane-kantin işletmecisi/çalışanı ve diğer okul çalışanlarına yönelik farkındalık eğitimlerinin yapılmasının sağlanması,

2. Öğretmenlerin; uzun süren ve düzelmeyen ishal, tekrarlayıcı ve sürekli karın ağrısı, karında şişlik, iştahsızlık, boy kısalığı, ergenlikte gecikme, kusma, kabızlık, kemik erimesi ve kansızlık gibi bulguları fark etmesi halinde öğrencinin çölyak hastası olabileceği konusunda aileyi uyarması,

3. Çölyaklı öğrencinin izni alınarak hastalığı ile ilgili diğer öğrencilerin bilgilendirilmesi ve öğrenciye besin ikramında 1srarcı olmamalarının sağlanması,

4. Okul/kurumdaki kutlama, sınıf içi ve sınıf dışı etkinliklerde besin ikramı yapılacaksa çölyaklı öğrenci velisinin mutlaka bilgilendirilmesi ve glütensiz besinlerin sağlanması için gerekli önlemlerin alınması,

5. Çölyak hastalığının şu anda kanıtlanmış tek tedavisi ömür boyu tam glütensiz diyettir. Bu nedenle; Çölyaklı öğrencilerin beslenmesinin sağlanabilmesi için kantinlerde, okul/kurum ve pansiyon yemekhanelerinde, gütensiz ürünlerin bulundurulması, glütensiz besin hizmetinin sağlanması için gerekli tedbirlerin alınması, 
6. Okul/kurum yönetimleri tarafindan kantin ve yemekhanede çalışan personele hangi besinlerin glüten içerdiği ve glütensiz besin pişirme ve saklama konusunda bilgilendirme yapilmas1,

7. E-okul sisteminde öğrencinin süreğen hastalığının yer aldığı bölüme çölyak tanısı konan öğrencilerin veri girişinin de düzenli olarak yapılması,

8. Çölyaklı öğrencilerin yaşam boyunca sağlıklarının korunması ve kendilerini güvende hissetmeleri için okul/kurumda gerekli tedbirlerin alınmasına yönelik yöneticiler, öğretmenler, veliler, kantin ve yemekhane işletmecisi/çalışanlarının yakın iş birliğinde olmasının sağlanması, maddeleri yer almaktadır.

\subsection{Yiyeceğe Erişim}

Okul öncesi eğitiminin verildiği anaokulları ve kreşler çocukların günün büyük bir kısmını geçirdikleri eğitim ortamlarıdır ve buralarda belirlenen menüler çocukların besin ve besin öğesi gereksinimlerini karşılar nitelikte olmalıdır (Çetin, 2019). Okul içerisinde belirlenen menülerin çölyak hastalığı gibi özel diyet gereksinimini zorunlu kılan hastalıkların varlığı durumunda daha özenli hazırlanmalı ve çocukların okul ortamında güvenli besinlere ulaşımı sağlanmalıdır (Çetin, 2019; T.C. Sağl1k Bakanlığı, 2018).

Dikkat edilmesi gereken en önemli hususlardan bir tanesi gerçekleştirilen sınıf içi/dış1 etkinliklerde besin ikramı yapılırken çok dikkatli olunması ve ısrar etmekten kaçınılmasıdır (T.C. Sağlık Bakanlığ1, 2018). Yapılacak olan etkinliklerden birkaç gün önce çocuğun velisi bilgilendirilmeli ve çocuğun diyetine uygun yiyecekler de ikramlara dahil edilmelidir (T.C. Sağlık Bakanlığ1, 2018). Bu konuda eğitimci ve veli arasındaki iletişim oldukça önemlidir. Aksi taktirde bu durum öğrencinin diyetini ihlali ya da sosyal içe çekilme ile sonuçlanabilmektedir.

Çocuk yatılı/pansiyonlu bir okulda öğrenim görüyorsa, mutlaka glütensiz depolama, hazırlama, pişirme ve servis alanı oluşturulmalıdır. Besin hazırlama alanlarında, depolama alanlarında glüten bulaşma riskini önleyecek güvenli ortamlar oluşturulmalıdır. Uygun ortamların hazırlanmadığ1 durumlarda çapraz bulaşmaya sebebiyet verilmiş olacaktır (T.C. Sağlık Bakanlığ1, 2018).

\subsection{Sosyal Etkinlikler}

Çölyak hastalığı eser miktarda bile olsa glütene maruziyet sonrasında belirti ve bulguların tekrar ortaya çıktığı bir hastalıktır. Glüten sadece yediğimiz yiyeceklerde değil kullanılan materyallerde de eser miktarda bile olsa bulunmaktadır. Bu bulaşın okul içerisinde önlenmesi ise öğretmenin konu 
ile ilgili bilgi düzeyine bağlıdır. Özellikle, bu maddelere maruz kalmak çocukların düşünce süreçlerini, duygularını, davranışlarını ve sosyal etkileşimlerini etkilemektedir (Clark, 2015).

Tablo 1'de belirtilen maddeler genellikle sınıflarda kullanılmaktadır ve değişen miktarlarda glüten içerir ve glüten maruziyeti çölyak belirtilerinin tekrardan görülmesine sebep olarak çocukların algılama süreçleri, duyguları, davranışları ve sosyal ilişkilerini olumsuz yönde etkilenmektedir (Clark, 2015). Sınıf ortamında glüten varlığının azaltılmasında en büyük rol yine okul öncesi öğretmenine düşmektedir. Okul öncesi öğretmenleri, yöneticiler ve okul danışmanları çocuklar üzerinde fiziksel ve psikolojik sağlık arasındaki ilişkiler konusunda psiko-eğitim sağlama olanağına sahiptir (Clark, 2015).

Tablo1. Glüten içeren ortak okul ürünleri (Clark, 2015).

\begin{tabular}{ll}
\hline Oyun hamuru & El Losyonları \\
Boyalar (Parmak ve Yüz) & Çıkartma \\
İşaretleyiciler & Yarabandı \\
Tutkal, Tutkal Çubukları ve Yapıştır & Güneş kremi
\end{tabular}

Okul öncesi öğretmeni, sınıf içi etkinliklerden okul gezilerine kadar yapılan tüm etkinliklerde, çölyaklı öğrencinin diyet gereksinimini göz önünde bulundurarak planlama yapmalı, veliyi yapılacak etkinlik konusunda önceden bilgilendirmeli ve öğrencinin damgalanmaması, sınıf ortamı içerisinde dışlanmaması için gerekli duyarlılı̆̆1 göstermelidir. Aksi taktirde çocuk kedisini ait olduğu toplumdan izole hissedebilir ve psikolojik bir içe çekilme yaşayıp aktivitelere katılımı kısıtlayabilir (T.C. Sağlık Bakanlığ1, 2018).

\subsection{Psikolojik Durum}

Çölyak hastalığını ve glütensiz beslenmeyi yönetmek zor olabilir çünkü çoğu zaman kendilerini izole hissederler ve etraftakilerden farklidirlar (Darling, 2013).

Darling (2013) çölyak hastalığı ile ilgili yaptığı bir araştırmasında; çalışmasındaki katılımcıların katılmış oldukları etkinliklerde etrafındakilerle aynı yiyeceği tüketemediklerinde kendilerini dışlanmış hissettiklerini belirtmiş ve bireylerin katıldıkları etkinliklerde başkalarıyla aynı yiyeceği yiyemedikleri zaman, izolasyon duygularının tetiklendiğini bulmuştur.

Öğrencinin etkinliklere dahil olmasını teşvik etmek için fiziksel ortamda değişiklik yapılabilir, ancak glütensiz ürünlere ulaşmak her zaman mümkün olmamaktadır, bu durum aile ile iş birliğini gerektirmektedir. (Clark, 2015). 
Öğretmenin bu durumu okul ve sınıf içerisinde etkin bir şekilde yönetebilmesi almış olduğu eğitim ile paraleldir. Etkinlikler öncesinde mutlaka ebeveynler ile iletişime geçilmeli ve çocuğun akranları ile etkileşimini engelleyecek tüm durumlar en aza indirgenmelidir. Çünkü çölyak hastalığı bulaşıcı ya da kişinin izolasyonunu gerektiren bir hastalık değildir.

Çölyak hastalığı hakkında bilgi eksikliği ve damgalama beraberinde öğrenci için çok zor bir sürecin başlangıcını tetiklemiş olmaktadır. Öğrencinin okul içerisinde ve en önemlisi sınıf içerisinde damgalanmanın önüne geçilmelidir. Çünkü bu durum öğrencinin eğitim hakkını da kısıtlamaktadır. Okul öncesi öğretmenleri ve yöneticilerinde desteği ile bu durum öğrenci/öğretmen eğitimi uygulamaları ile giderilebilir.

\section{SONUÇLAR}

Çölyak hastalığı, yaşam boyu devam eden ve mevcut tek tedavisi glütensiz diyet olan otoimmün bir hastalıktır. Çölyak hastalı̆̆ı yalnızca beslenme ile ilgili bir sorun olmayıp teşhis ve tedavi sürecine hatta tam bir uyum sağlanana kadar hastanın sosyal ve psikolojik olarak yaşam kalitesini etkilemektedir.

Gününün büyük bir kısmını okulda geçirildiği düşünüldüğünde, iyi ve sağlıklı beslenme çocukların bilişsel ve davranışsal becerilerinin gelişimini kolaylaştırır ve öğrenme potansiyellerini tamamlamasını sağlar. Bu dönemde özellikle çölyaklı çocuğun kendi durumunun farkında olması ve günlük ihtiyaçlarını bu çerçevede gerçekleştirmesi bedensel sağlı̆̆1 ve psikolojik gelişimi açısından önemlidir. Bu sorumlulukların yerine getirilmesi ve farkındalığın sağlanabilmesinde okul ortamındaki en büyük rol eğitimcilere düşmektedir. Erken çocuklukta teşhis alan anaokulu öğrencileri için mutlak çevre düzenlemesi öğretmenlerin çölyak ile ilgili sahip oldukları bilgi düzeyi ile mümkündür. Bu nedenle okul öncesi dönemde özellikle çöyak gibi diyet ve özel beslenme gerektiren hastalıklar konusunda okul yöneticileri ve okul öncesi öğretmenlerinin bilgi düzeyi ve farkındalıklarının arttırılması büyük bir önem teşkil etmektedir.

\section{Öneriler}

Okulda sağlık sorunu olan öğrencinin tespiti için öğrenci ile ilk karşılaşmada sağlık ile ilgili edinilen bilgiler çok önemlidir ve bu bilgiler 1şı̆̆ında okulda eğitim faaliyetleri düzenlenmelidir.

Çölyak hastalığının eğitim kurumlarınca etkin bir şekilde öğrencinin yararına yönetilebilmesi için öncelikle öğrencinin mensup olduğu sınıfın öğretmeninin akabinde ise diğer eğitim kadrosunun bilgilendirilmesi sağlanmalıdır. 
Okul hemşiresi varsa çölyak ile ilgili tanı, tedavi, belirti, acil durum belirtileri ve neler yapılacağı konusunda ilgili öğretmen ve diğer öğretmenlerin eğitiminin sağlanması gerekmektedir.

Çölyaklı öğrenciye okula kabulünden başlayarak her aşamada akranları gibi davranılması ve okulda ya da sınıf içinde yapılacak her türlü etkinlikte tam katılımın sağlanması için çabalamak ve yapilacaklar konusunda aileyi bilgilendirmek gerekmektedir.

Sınıf içinde yapılan etkinliklerde kullanılan materyallerin çölyaklı öğrenci için uygun malzemelerden üretilmiş olanı temin edilmeli ya da bu konuda ailenin yardımı talep edilmelidir.

Sınıf içinde yapılan yiyecekli etkinliklerde ise menü çölyaklı öğrencinin katılımını kısıtlayıcı şekilde seçilmemeli ya menü buna göre belirlenmeli ya da aileden öğrencinin özel diyetine uygun yiyeceklerin getirilmesi istenmelidir. Öğrencinin güvenli yiyeceğe erişimi sağlanmalıdır.

Okul kantin/yemekhanesinde çölyak ve diğer diyet gereksinimi olan öğrencilerin erişimini sağlayabileceği yiyeceklere yer verilmelidir.

Okullarda gıda işletmelerinde (yemekhane, kantin, büfe, çay ocağı, kafeterya vb.) çalışanlarının da çölyak hastalı̆̆ı konusunda bilgilendirilmesi sağlanmalıdır.

Eğitimde firsat eşitliği ilkesine bağlı kalınarak öğrencinin eğitimini kısıtlayacak her türlü durumun önüne geçilmelidir.

Her y1l 9 Mayıs Dünya Çölyak Günü’ünde ‘Çölyakla Yaşam’ konulu programlar düzenlenmelidir.

Çölyak hastalığı, Dünyada ve Ülkemizde gittikçe artan sıklıkta görülmeye başlayan bir hastalıktır. Ancak literatüre bakıldığında çölyak hastalığına ait klnik çalışmalara ulaşmak mümkünken, Çölyaklı ailelerin ve çocukların;

○ Okul ve sosyal ortamlarda yaşadığı uyum sorunları,

○ Yiyeceğe erişim konusunda etiket okuma becerisi

- Okul çocuğu ve arkan ilişkilerinin çocuğun sosyal ilişkilerine olan etikisi

○ Çölyaklı çocuk ve okul ilişkisini inceleyen herhangi bir araştırmaya rastlanmamıştır. Belirtilen konular ile yapılacak olan akademik çalışmalar literatür için bir kaynak teşkil edecektir. 


\section{KAYNAKÇA}

Akder RN, Meseri R ve Çakıroğlu FP (2018). Okul çağı çocukluk döneminde beslenme eğitimi, Ankara Sağlk Bilimleri Dergisi. (2), 1-10.

Aktaç Ş, Kızıltan G ve Avcı S (2019). Beslenme eğitimi müdahalesine aile katılımının okul öncesi dönemdeki çocukların beslenme durumlarına etkisi. Eğitim ve Bilim Dergisi-TEDMEM. (199), 415-431.ERIŞSIM TARİHİ: 18.07.2019.

Altundağ S (2018). Tip 1 diyabetli çocukların hastalığa uyumunda eğitimin ve sosyal desteğin etkisi. Pamukkale Thp Dergisi. 11(2):137-144.

Aşı1k ZN (2019). İç hastalkklar hekimleri ve aile hekimlerinde çölyak hastalğ̆ farkındalı düzeyinin belirlenmesi. (Yayımlanmamış Tipta Uzmanlık Tezi). T.C Sağlık Bilimleri Üniversitesi Okmeydanı Sağlık Uygulama ve Araştırma Merkezi, İstanbul.

Barzegar F, Rostami-Nejad M, Shalmani HM, Sadehi A, Khani MA and Aldulaimi M (2017). The effect of education on the knowledge of patients with celiac disease. Gastroenterology and Hepatology From Bed to Bench. ERIŞIM TARIHİ: 03.12.2017.

Bulsa GC, Bulsa M (2018). Adherence to gluten-free diet in children with celiac disease. nutrientsOpen Access Journal. 10(10), 1424. 4 October 2018.

Canadian Celiace Association [CCA ](2007). Celiace desiase teacher's info. 01 Şubat 2020 tarihinde http.www.celiac.ca adresinden erişildi.

Clark AA (2015). The gluten-free zone: school considerations for childhood celiac disease. VISTAS 2015, ACA Knowledge Center.http://www.counseling.org/knowledgecenter/vistas.

Çakmak A (2013). Ankara'da yaşayan 19-65 yaş arası çölyak hastalarmm beslenme durumlarmm yaşam kalitesi üzerine etkisi. (Yayımlanmamış Yüksek Lisans Tezi). Hacettepe Üniversitesi Sağllk Bilimleri Enstitüsü, Ankara.

Çetin NK (2019). Kreşlerde uygulanan menüler ve çocuklarn beslenme durumunun değerlendirilmesi. (Yayımlanmamış Yüksek Lisans Tezi). Hacettepe Üniversitesi Sağlık Bilimleri Enstitüsü, Ankara.

Darling AA (2013). Exploring factors of non-compliance for adolescents with celiac disease. https://sophia.stkate.edu/mswpapers/167. ERIȘIM TARİHI: 5.2013

Elliiki Z (2019). Cölyak hastalĭg tanısı almıs kişilerde glütensiz diyetin psikososyal durum ve yaşam kalitesi üzerine etkisi. (Yayımlanmamış Yüksek Lisans Tezi) İstanbul: İstanbul Üniversitesi sağlık Bilimleri Enstitüsü 
Emiroğlu HL, Emiroğlu M, Akbulut H, Eryılmaz A, Bayram RO, Yüksel A ve Ağır MA (2017). Clinical characteristics in children with celiac disease: a single center results. Journal of Contemporary Medicine. (4): 333-339

Gündüz S, Çizmeci MN ve Kanburoğlu MK (2013). Okul öncesi eğitim kurumlarındaki öğretmenlerin çocuk sağlığı konusundaki bilgi düzeyleri. Türkiye Cocuk Hastalıklar Dergisi (1): 21-26.

Kuloğlu Z (2014). Çölyak hastalığ1. Turkish Journal of Pediatric Disease. (2): 105-111

Küçükazman M, Ata N, Dal K ve Nazlıül Y (2008). Çölyak hastalığı. Dirim Tıp Gą̣etesi say:83(85-92).

Mokhtari H (2012). Çölyak hastaluğ tanıs alan çocuklarda şişmanlık sıkliğ ve glütensiz diyetin vücut kitle indeksine etkisi. (Yayımlanmamass Çocuk sağlığı ve Hastalıları Uzmanlık Tezi), Ankara Üniversitesi Tıp Fakültesi. Ankara.

Meyer S and Rosenblum S (2017). Activities, participation and quality of life concepts in children and adolescents with celiac aisease: A Scoping Review. 24 August 2017. 9(9)- 929.

Özkaya V, Özkaya ŞÖ (2018). Çölyak hastalı̆̆ına diyetetik yaklaşım. Selcuk Medical Journal. 34(4): 186-193.

Sedakatlı FA (2019). Okul çağı cocuklarna verilen beslenme eğitimi programının beslenme alı̧̧kanlıklar besin tüketim sılklklar ve beslenme bilgisi üæerine etkisinin değerlendirilmesi. (Yayımlanmamış Yüksek Lisans Tezi). Selçuk Üniversitesi Sosyal Bilimler Enstitüsü, Konya

Serin Y ve Akbulut B (2017). Çölyak hastalığ1 ve glütensiz diyet tedavisine güncel yaklaşım. Turkiye Klinikleri Journal of Health Sciences. 2(3):192-200 19.12.2016

Şahinöz T, Şahinöz S ve Kınavç A (2017). Sağlığı geliştirmenin en kolay yolu: okul sağllğı. Gümüshane ÜniversitesiSağhlk. Bilimleri Dergisi.. 6(4):303-312

Tanpowpong P, Ingham TR, Lampsihire PK, Kirchberg FF, Epton MJ, Crane J and Camargoca JR (2011). Celiac disease and gluten avoidance in new zealand children. https://journals.bmj.com/. 97(1):12-6. 10 November 2011.

Türkiye Cumhuriyeti Milli Eğitim Bakanlığı (2018). Çölyakla mücadele kapsamında yapılacak çalışmalar. Erişim Tarihi: 10.04.2018

Türkiye Cumhuriyeti Sağlık Bakanlığ1 (2018). Çölyak hastalığ1 öğretmenlere yönelik bilgilendirme rehberi. Ankara.(https://hsgm.saglik.gov.tr/depo/birimler/saglikli-beslenme-hareketli$\underline{\text { hayat }}$ $\mathrm{db} /$ Yayinlar/rehberler/Colyak Hastaligi Ogretmenlere Yonelik Bilgilendirme Rehberi. pdf):ERIŞIM TARİHi: 23.05.2018

Türksoy Ş ve Özkaya B (2006). Glüten ve çölyak hastalığı. Türkiye 9. Gıda Kongresi; 24-26 Mayıs 2006, Bolu: Ankara, Ankara Üniversitesi Mühendislik Fakültesi, G1da Mühendisliği Bölümü. 
Yıldız EP ve Civan HA (2019). Pediyatrik çölyak hastalarının nörolojik ve psikososyal değerlendirilmesi: diyete uyumları-olgu kontrol çalışması. Bakırkëy T⿰力丶 Dergisi. 15:110-4.

Y1lmaz G (2008). Kronik hastalŭğ olan ilkö̈rretim ögrencilerinde aile okul ilişkisi. (Yayımlanmamış Yüksek Lisans Tezi). Atatürk Üniversitesi. Sağlık Bilimleri Enstitüsü, Erzurum.

Yönal O ve Özdil S (2014). Çölyak hastalığı. Memorial Şişli Hastanesi, Gastroenteroloji Bölümü Güncel Gastroenteroloji Dergisi 18/1 İstanbul

Zembat R, K1lıç Z, Ünlüer E, Çobanoğlu A, Usbaş H ve Bardak M (2015). Çocuğun beslenme alışkanlığını kazanmasında okul öncesi eğitim kurumlarının yeri. Hacettepe Unversity Faculty of Health Sciences Journal. Vol (1)2 (417-424) 